\title{
Siyah üzüm çekirdeği tozunun yoğurtların bazı fizikokimyasal, mikrobiyolojik ve duyusal özellikleri üzerine etkisi
}

\author{
Alperen KALYAS ${ }^{\circledR 1}$, Bayram ÜRKEK ${ }^{(D)}$ \\ ${ }^{1}$ Gümüşhane Üniversitesi, Fen Bilimleri Enstitüsü, Gıda Mühendisliği ABD, Gümüşhane \\ ${ }^{2}$ Gümüşhane Üniversitesi, Şiran Mustafa Beyaz Meslek Yüksekokulu, Gıda İşleme Bölümü, Gümüşhane
}

Alınıș tarihi: 19 Mart 2020, Kabul tarihi: 3 Temmuz 2020

Sorumlu yazar: Bayram ÜRKEK, e-posta: bayramurkek@gumushane.edu.tr

\section{Öz}

$\mathrm{Bu}$ çalışmada, \%0 kontrol numunesi ve farklı oranlarda $(0, \% 0.5$ ve \%1) siyah üzüm çekirdeği tozu (ÜÇT) ilave edilen yoğurtların bazı kalite özellikleri incelenmiştir. pH değerleri depolama süresine bağlı olarak düşerken, asitlik değerleri ÜÇT ilavesiyle yükselmiştir. Tüm örneklerin serum ayrılması değerleri depolamanın sonunda düşmüştür. \%1 ÜÇT içeren örnek örneğin en yüksek viskozite (50 ve 100 rpm) ve kıvam katsayısı değerlerine sahip olduğu gözlenmiştir. $L^{*}, b^{*}, C^{*}$ ve beyaz indeksi değerleri ÜÇT ilavesiyle düşmüş, sadece $a^{*}$ değerleri yükselmiştir. $\% 0.5$ ve \%1 ÜÇT içeren yoğurt örneklerinin tüm duyusal özellikler bakımından kontrol örneğinden daha düşük puanlara sahip olduğu bulunmuştur. Sonuç olarak, ÜÇT doğal bir renklendirici kaynağı olarak, yoğurtların reolojik değerlerini ve viskozitesini düzeltmek için kullanılabilir. Yoğurt örneklerinin duyusal özelliklerini, ÜÇT ilavesi olumsuz etkilediğinden, yoğurda \%0.5 den daha düşük konsantrasyonlarda ÜÇT ilavesi denenmelidir.

Anahtar kelimeler: Yoğurt, Siyah Üzüm Çekirdeği Tozu, Mikrobiyolojik Özellikler, Viskozite, Duyusal Özellikler

Effect of black grape seed powder on the physicochemical, microbiological and sensory properties of yoghurts

\footnotetext{
Abstract

In this research, some quality properties of yoghurts produced by adding black grape seed powder (GSP) in different proportions $(0 \%, 0.5 \%$ and $1 \%)$ were
}

investigated. $\mathrm{pH}$ values decreased depending on storage period, while acidity values increased with addition of GSP. While $\mathrm{pH}$ values decreased during storage, acidity values increased with the addition of GSP. Syneresis values of all samples decreased at the end of storage. The sample containing 1\% GSP had the highest viscosity (50 and $100 \mathrm{rpm}$ ) and consistence coefficient values. $\mathrm{L}^{*}, \mathrm{~b}^{*}, \mathrm{C}^{*}$ and white index values of yoghurt samples decreased with addition of GSP, only $\mathrm{a}^{*}$ values increased. The yoghurt samples including $0.5 \%$ and $1 \%$ GSP had lower score than control sample in terms of all sensory properties. As a result, GSP can be used as a natural colorant source to improve rheological properties and viscosity of yoghurts. The addition of GSP should be tested in lower concentrations in yoghurt than $0.5 \%$ concentration. Because, sensory properties of yoghurts were negatively affected by addition of GSP.

Key words: Yoghurt, Black Grape Seed Powder, Microbiological Properties, Vicosity, Sensory Properties.

\section{Giriş}

Yoğurdun terapötik, besleyici ve duyusal özellikleri uzun zamandır bilinmektedir. Yoğurt tüm dünyada bilinen fermente süt ürünüdür (Şengül ve ark., 2012). Yoğurt üretiminde fermentasyon için kullanılan Lactobacillus delbrueckii subsp. bulgaricus (L. bulgaricus) ve Streptococcus thermophilus (S. thermophilus) (Brückner-Gühmann ve ark., 2019) sağlığa faydaları olan mikroorganizmalardır. Yoğurtların besleyici, reolojik ve tekstürel özelliklerini iyileștirmenin yolları araştırılmaktadır. Bunun içinde farklı ürünler ilave edilmektedir 
(Şengül ve ark., 2012; Chouchouli ve ark., 2013; Demirkol ve Tarakci, 2018).

Üzüm dünyanın en geniş ekim alanına sahip meyvelerden birisidir (Marchiani ve ark., 2016). Türkiye üzüm üretimi bakımından dünyada ilk sıralarda olup (Anonim, 2018), üretilen üzümün büyük bir kısmı sofralık olarak tüketilmekte, bunun dışında üzüm şarap, alkol, sirke pekmez gibi ürünlerin üretiminde kullanılmaktadır (Bashimov, 2017). Dünyada ise genel olarak üretilen üzümün büyük kısmı meyve suyu ve şarap üretiminde kullanılmaktadır. Üretim sırasında üzüm ağırlığının büyük bir kısmını kabuk ve çekirdekten oluşan atık olarak kaybetmektedir (de Souza ve ark., 2015; Marchiani ve ark., 2016). Oluşan bu atıkların uzaklaştırılması da atıkların içeriği nedeniyle oldukça zor ve pahalıdır. Çevreye atılması durumunda ciddi problemlere neden olabilmektedir (Marchiani ve ark., 2016).

Üzüm yan ürünleri fitokimyasallar bakımından oldukça zengindir (Chouchouli ve ark., 2013). Özellikle de fenolik asitler ve flavonoid gibi fenolik bileşiklerin başlıca kaynağıdır (Rockenbach ve ark., 2011; Rosales Soto ve ark., 2012; Marchiani ve ark., 2016). Fenolik bileşikler antioksidan, antiiflamatuar, yaşlanmayı geciktirici, kardiyovasküler hastalıkları önleyici özelliklere sahiptir (Karaaslan ve ark., 2011; Marchiani ve ark., 2016). Bu nedenle fenolik bileşiklerin insan sağlığı üzerinde hastalıkları önleyici etkileri nedeniyle takviye edici gıda veya birçok gıda endüstrisinde gıda katkı maddesi olarak kullanılmaya başlanmıştır (Karaaslan ve ark., 2011; Rockenbach ve ark., 2011). Aynı zamanda üzüm çekirdeği ve posası antioksidan olan flavonoid bileşiklerinin ekstraksiyonu için de ucuz bir kaynaktır (Rockenbach ve ark., 2011). Üzüm çekirdeği ve posası antosiyaninler bakımından da zengindir. Antosiyaninler sahip olduğu parlaklık, çekici renk ve suda kolay çözünmesi nedeniyle yapay renklendiricilerin yerine gıdalarda kullanılmaktadır (Rockenbach ve ark., 2011; de Souza ve ark., 2015).

Polifenoller üzüm çekirdeğinde bulunan en önemli bileşiklerdir (Al-Taie, 2014) Yoğurtlarda fenolik bileşikler yoğurdun fonksiyonel özelliklerini iyileştirmek ve fenolik bileşiklerin insanlar tarafından tüketilmesini sağlamak amacıyla ilave edilebilir. Bunun yanında yoğurtlara fenolik bileşiklerin ilavesiyle yoğurtların asitliği, depolama ve fermantasyon süresince mikrobiyal gelișimi iyileşmekte ve ürünün yapısal ve duyusal özellikleri geliştirilebilmektedir. (da Silva ve ark., 2017). da
Silva ve ark. (2017) yoğurda 1.5 ve $3 \mathrm{~g} / \mathrm{L}$ oranında üzüm ekstarktı ilave etmişler ve yoğurtların fiziksel, reolojik ve mikrobiyolojik özelliklerini incelemişlerdir. Araştırma sonucunda, üzüm ekstraktı ilave edilen örneklerin daha yumuşak bir tekstüre sahip olduğunu, serum ayrılması, kıvam katsayısının yükseldiğini, mikrobiyoljik ve duyusal açıdan herhangi bir olumsuz etksinin olmadığını belirlemişlerdir. Üzüm çekirdeği ekstraktı (Karaaslan ve ark., 2011; Chouchouli ve ark., 2013), üzüm ekstraktı (da Silva ve ark., 2017) ve üzüm posası (Demirkol and Tarakci, 2018) gibi üzüm ve yan ürünleri ilavesinin yoğurtlarda yapılan farklı çalışmalarda araştırıldığı belirlenmiştir. $\mathrm{Bu}$ çalışmada farklı oranlarda ilave edilmiş siyah üzüm çekirdeği tozunun (ÜÇT) yoğurtların fizikokimyasal, mikrobiyolojik ve duyusal özellikleri üzerine etkisinin araştırması amaçlanmıştır.

\section{Materyal ve Yöntem}

\section{Materyal}

Siyah üzüm çekirdeği (Vitis vinifera) tozu piyasadan (Natural Hekimce - Aksuvital Doğal Ürünler A.Ş.), tam yağlı inek sütü Şiran Süt A.Ș.'den temin edilmiștir. Yoğurt örneklerinin üretimi L. bulgaricus, S. thermophilus içeren DVS Y0-130 (Biochem s.r.l.. Roma, İtalya) starter yoğurt kültürü kullanılarak gerçekleștirilmiştir. Yoğurt Gümüşhane Üniversitesi Şiran Mustafa Beyaz Meslek Yüksekokulu Fen ve Gıda Laboratuvarında üretilmiștir.

\section{Yöntem}

\section{Yoğurt üretimi}

Sütün kurumadde oranı yaklaşık \%15.5 olarak yağsız süt tozu ile standardize edilmiștir. Kullanılan sütün yağ oranı \%3,2, kurumadde oranı \%12,13, pH'ı 6,67 ve titrasyon asitliği ise $\% 0,17$ olarak belirlenmiştir. Kurumaddesi standardize edilmiș süte siyah üzüm çekirdeği tozu (ÜÇT), \%0.5 (ÜÇT1), \%1 (ÜÇT2) oranlarında ilave edilmiştir (Şekil 1). Bu oranlar daha önce yapılan benzer çalışmalardaki kullanılan miktarlar dikkate alınarak belirlenmiștir (Demirkol ve Tarakci, 2018). Sütler $85^{\circ} \mathrm{C}$ 'lik ısıda 20 dakika bekletilerek pastörize edildikten sonra 42-45 ${ }^{\circ}$ 'ye soğutulan sütlere DVS starter kültürden (\%2) ilave edilmiştir. İnkübasyon için sütler steril kaplara aktarılmıştır ve $43{ }^{\circ} \mathrm{C}^{\prime}$ de inkübe edilmiştir. Yoğurtlarda, fermantasyon işlemini $\mathrm{pH}$ değerleri 4.7'ye düştüğünde son verilmiştir. Deneme örnekleri $+4{ }^{\circ} \mathrm{C} 28$ depolanmış ve depolamanın 1, 14 ve 28 . günlerinde örneklerin analizleri yapılmıştır. 


\section{Yoğurtlarda asitlik, pH ve serum ayrılması}

Yoğurt örneklerinin toplam asitliği değeri titrasyon yöntemi ile $0.1 \mathrm{~N} \mathrm{NaOH}$ kullanılarak belirlenmiştir. Sonuçlar \% laktik asit olarak verilmiştir. $\mathrm{pH}$ değerleri birleşik elektrodlu $\mathrm{pH}$ metre yardımı ile belirlenmiştir (Metin, 2009). Ölçümlerde WTW Profline pH 3110 pH metre kullanılmıştır.

Yoğurt örneklerinin serum ayrılması tayininde iki farklı yöntem kullanılmıştır. İlk yöntemde $25 \mathrm{~g}$ yoğurt örneği tartılmış $+4^{\circ} \mathrm{C}$ 'de 120 dak bekletilerek kaba filtre kağıdından süzülen kısım mezür ile ölçülmüştür (Atamer ve Sezgin, 1986). Diğer yöntemde yoğurt örneklerinde serum ayrılmasının belirlenmesinde santrifüj yöntemi kullanılmıştır. Bunun için 10 g yoğurt örneği bir tüpe tartılmış, 220 $x g^{\prime}$ de 20 dak $+4{ }^{\circ} C^{\prime}$ de santrifüjlenmiştir (GuénardLampron ve ark., 2019). Ayrılan berrak kısım g olarak tartılmış $10 \mathrm{~g}$ yoğurttan ayrılan serum miktarı olarak ifade edilmiştir.

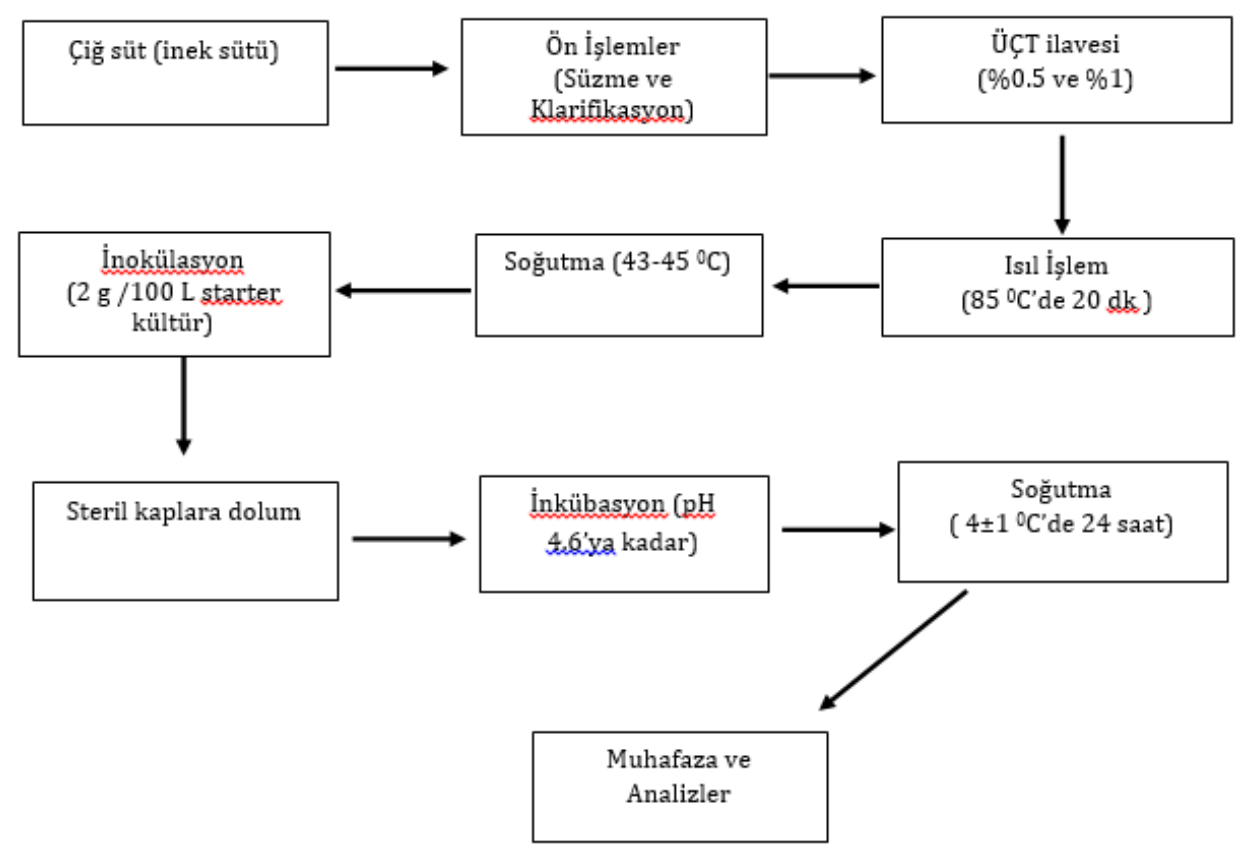

Şekil 1.Yoğurt üretim akıș șeması

\section{Yoğurtların viskozite ve reolojik özellikleri}

Yoğurt örneklerinin viskozite ölçümlerinde viskozimetre (Brookfield Viscometer Model DV-II) cihazı ve 6 numaralı başlık kullanılmıştır. Örnekler 30 sn süre ile $5,10,20 . \ddot{u}, 50$ ve $100 \mathrm{rpm}$ rotasyonal hızlarla karıștırılmış, sonuçlar centipoise (cP) olarak açılklanmıştır (Akin ve ark., 2007). Örneklerin reolojik parametrelerinin belirlenmesinde "Power Law" modelinde yararlanılmış ve aşağıdaki formüle göre (1) hesaplanmıştır. $\mathrm{Bu}$ formülde görünür viskozite (Pa.s) $\eta$ ile, kıvam indeksini $K$ ile, kayma hızını (rpm) $\gamma$ ile ve akış davranış indeksi ise $n$ ile gösterilmiştir. Yoğurt örneklerinin viskozite ve reolojik özellikleri ile ilgi analizler depolamanın 28. gününde yapılmıştır.

$\eta=K \gamma^{(\mathrm{n}-1)}$

\section{Yoğurtlarda renk parametreleri}

Yoğurt örneklerinin renk parametreleri CR-200 Minolta kolorimetre (Minolta Camera Co., Osaka, Japan) ile belirlenmiştir. Kolorimetre standart beyaz porselen ile kalibre edildikten sonra ölçümler yapılmıştır. Kolorimetrede $L^{*}$ (parlaklık; 0: siyah, 100: beyaz), $a^{*}$ (+: kırmızı; -: yeşil) ve $b^{*}$ (+: sarı; -: mavi) değerleri ölçülmüştür. Hue dereceleri $\left(H^{\circ}\right)$ renk parametrelerinin yeknesak sunumunu sağlar. Hue derecelerine göre $0^{\circ}$ ve $360^{\circ}$ kırmızl, $90^{\circ}$ sarl, $180^{\circ}$ yeşil ve $270^{\circ}$ mavi renktir. $H^{\circ}$ belirlenmesinde McLellan ve ark. (1995) tarafindan tanımlanan formül kullanılmıștır. Renk doygunluğu $\left(C^{*}\right)$ bir örneğin renkliliğini göstermektedir. $\Delta E^{*}$ ise iki renk arasındaki farklılığı belirlemede kullanılmaktadır. Buna göre renk farklılıklarının $\Delta E^{*}<1$ ise algılanamaz, $1 \leq \Delta E^{*}<2$ ise çok az düzeyde, $2 \leq \Delta E^{*}<3$ ise sadece alglanabilir, $3 \leq \Delta E^{*}<5$ ise alglanabilir, 
$5 \leq \Delta E^{*}<12$ ise kesin farklılıklar, $\Delta E^{*} \geq 12$ ise iki rengin tamamen farklı olduğunu göstermektedir (Cecchini ve ark., 2011). Beyaz indeksi Kurt ve Atalar (2018) tarafından tanımlanan yöntemle belirlenmiştir. Renk analizleri depolamanın 28. gününde yapılmıștır.

\section{Yoğurtların mikrobiyolojik analizleri}

Yoğurt örneklerinden $10 \mathrm{~g}$ örnek alınarak 90 mL'lik steril \%0.85 (w/v)'lik tuz çözeltisine ilave edilmiştir. Yoğurt örnekleri stomacher cihazında (InterscienceBagmixer 400 P, St Nom, Fransa) homojenize edildikten sonra \%0.85 tuz içeren çözelti ile seri dilüsyonlar hazırlanmıştır. S. thermophilus sayımı için M17 (Merck, Darmstadt, Almanya) agar kullanılmıştır. Besiyerleri $37{ }^{\circ} \mathrm{C}^{\prime}$ de 48 saat aorebik şartlarda inkübe edildikten sonra oluşan koloniler sayılmıştır (Sendra ve ark., 2008). L. bulgaricus sayıları, MRS (Merck, Darmstadt, Almanya) agarın 37 ${ }^{\circ} \mathrm{C}$ 'de 72 saat anaerobik ortamda inkübe edildikten sonra oluşan koloniler saylarak belirlenmiștir (Chouchouli ve ark., 2013). Yoğurt örneklerinin maya küf sayısını belirlemek için \%10'luk tartarik asit (14 mg/L) ilave edilen PDA (Patato Dextroz Agar; Merck, Darmstadt, Almanya) kullanılmıștır. Besiyerleri $25{ }^{\circ} \mathrm{C}$ 'de 5 gün inkübe edildikten sonra oluşan koloniler sayılmıştır Mikrobiyolojik analizler depolamanın 1., 14. ve 28. günlerinde yapılmış ve sonuçlar log kob/g olarak verilmiştir.

\section{Duyusal analiz}

Yoğurt örneklerinin duyusal değerlendirilmesi duyusal analizler konusunda eğitilmiş, yoğurt tüketen yaşları 25 ile 40 arasında 10 (4 kadın, 6 erkek) akademik personel tarafından yapılmıştır. Panelistler örnekleri renk ve görünüş, yapı ve tekstür, lezzet, tat ve koku, ağızda bıraktığı his ve genel kabul edilebilirlik özellikleri bakımından hedonik skalaya göre değerlendirmişler ve 1 ile 9 arasında bir değer vermişlerdir (Meilgaard ve ark., 1999). Yoğurt örneklerinin duyusal analizi depolamanın 28. gününde yapılmıștır.

\section{İstatistik analiz}

Araştırma iki tekerrürlü yürütülmüş olup, sonuçlar

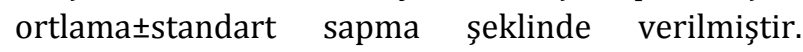
Araştırmada elde edilen verilere SPPS (SPSS 17 Corp. Inc.) istatistik paket programında "Tek Yönlü Varyans Analizi (one-way ANOVA)" uygulanmıştır. Önemli çıkan farklılıklar Duncan Çoklu Karşılaştırma Testi ile belirlenmiştir. Harfler istatistiksel farklılıkların ifade edilmesinde kullanılmıştır.

\section{Bulgular ve Tartışma}

\section{Asitlik, pH ve serum ayrılması}

Yoğurt örneklerinin asitlik ve pH değerleri ÜÇT ilavesinden ve depolamadan istatistiksel olarak etkilenmiştir $(\mathrm{P}<0.01)$. Örneklerin her iki yöntemle elde edilen serum ayrılması değerleri üzerine depolamanın etkisi önemsiz iken $(\mathrm{P}>0.05)$, sadece santrifüj yöntemiyle serum ayrılması değerleri üzerine ÜÇT'nin etkili olduğu $(\mathrm{P}<0.01)$ belirlenmiştir. Tüm yoğurt örneklerinde $\mathrm{pH}$ değerleri depolamanın 1. gününde en yüksek iken depolama süresince düşmüştür (Çizelge 1). Örnekler arasında farklılık sadece depolamanın 28. gününde belirlenmiş olup kontrol örneğinin $\mathrm{pH}$ değerinin diğer örneklerden yüksek olduğu tespit edilmiştir. Marchiani ve ark., (2016) yoğurtlara üç faklı cins üzümden elde edilen posa ilave etmiş, yoğurtların özelliklerini incelemişlerdir. Yaptıkları çalışmada yoğurtların $\mathrm{pH}$ değerlerinin depolama süresince düştüğünü bulmuşlardır. Demirkol ve Tarakci (2018) farklı şekillerde kuruttukları üzüm posalarının tozlarından yoğurtlara farklı oranlarda eklemiş, yoğurtların fizikokimyasal, mikrobiyolojik ve biyoaktivite özelliklerini araştırmışlardır. Yoğurt örneklerinin $\mathrm{pH}$ değerlerinin depolama süresince değiștiğini bulmuşlardır. $\mathrm{Bu}$ sonuçlar bizim bulduğumuz sonuçlar ile benzerlik göstermektedir. Yoğurt örneklerine ait asitlik değerleri Çizelge 1'de verilmiştir. Asitlik değerleri kısmen pH değerleri ile uyuşmaktadır. Örneklerin asitlik değerleri \%0.84 ile \%0.99 arasında tespit edilmiştir. ÜÇT1 ve ÜÇT2 kodlu örneklerin asitlik değerleri depolamanın 14 . ve 28. günlerinde depolamanın 1. gününe daha yüksek olduğu bulunmuştur. Bununla birlikte kontrol örneğinin asitlik değerinde depolama sürecinde önemli bir değişim belirlenmemiştir $(P>0.05)$. Depolamanın 1. ve 28. gününde ÜÇT1 ve ÜÇT2 kodlu örneklerin asitlik değerleri kontrol örneğine göre daha yüksek iken, depolamanın 1 . gününde örnekler arasında istatistiksel olarak önemli bir değişiklik meydana gelmediği tespit edilmiştir ( $\mathrm{P}>0.05)$. Demirkol ve Tarakci (2018) yaptıkları çalışmada yoğurtların asitlik değerlerinin 21 günlük depolama süresinin sonunda $\% 0.88$ ile \%1.07 arasında bulmuşlardır. Marchiani ve ark. (2016) üzüm posası ile zenginleştirdiği yoğurtların asitlik değerlerini 21 günlük depolama sonunda \%0.99 ile \%1.07 arasında değiștiğini tespit etmişlerdir. Bu değerler bizim 28 günlük depolama sonunda bulduğumuz titrasyon asitliği (\%0.85\%0.99) değerlerinden daha yüksektir. 
Çizelge 1. Siyah üzüm çekirdeği tozu eklenmiş örneklerin pH, titrasyon asitliği ve serum ayrılması

\begin{tabular}{|c|c|c|c|c|}
\hline & \multirow{2}{*}{$\begin{array}{c}\text { Depolama } \\
\text { Süresi (gün) }\end{array}$} & \multicolumn{3}{|c|}{ Yoğurt Örnekleri } \\
\hline & & $\mathrm{K}$ & ÜÇT1 & ÜÇT2 \\
\hline \multirow[b]{2}{*}{$\mathrm{pH}$} & 1 & $4.54 \pm 0.00^{\mathrm{a}, \mathrm{C}}$ & $4.55 \pm 0.01^{\mathrm{a}, \mathrm{C}}$ & $4.54 \pm 0.00^{\mathrm{a}, \mathrm{C}}$ \\
\hline & 14 & $4.44 \pm 0.01^{\mathrm{a}, \mathrm{B}}$ & $4.44 \pm 0.01^{\mathrm{a}, \mathrm{B}}$ & $4.44 \pm 0.01^{\mathrm{a}, \mathrm{B}}$ \\
\hline \multirow{4}{*}{$\begin{array}{l}\text { Titrasyon asitliği } \\
\text { (\%) }\end{array}$} & 28 & $4.27 \pm 0.01^{\mathrm{b}, \mathrm{A}}$ & $4.22 \pm 0.02^{\mathrm{a}, \mathrm{A}}$ & $4.20 \pm 0.01^{\mathrm{a}, \mathrm{A}}$ \\
\hline & 1 & $0.84 \pm 0.01^{\mathrm{a}, \mathrm{A}}$ & $0.87 \pm 0.01 \mathrm{~b}, \mathrm{~A}$ & $0.89 \pm 0.01 \mathrm{~b}, \mathrm{~A}$ \\
\hline & 14 & $0.95 \pm 0.04^{\mathrm{a}, \mathrm{A}}$ & $0.97 \pm 0.04^{\mathrm{a}, \mathrm{B}}$ & $0.98 \pm 0.02^{\mathrm{a}, \mathrm{B}}$ \\
\hline & 28 & $0.85 \pm 0.05^{\mathrm{a}, \mathrm{A}}$ & $0.99 \pm 0.04 \mathrm{~b}, \mathrm{~B}$ & $0.98 \pm 0.01^{\mathrm{b}, \mathrm{B}}$ \\
\hline \multirow{3}{*}{$\begin{array}{l}\text { Serum ayrılması } \\
(\mathrm{mL} / 25 \mathrm{~g})\end{array}$} & 1 & $7.10 \pm 0.14^{\mathrm{a}, \mathrm{B}}$ & $7.40 \pm 1.98^{\mathrm{a}, \mathrm{A}}$ & $7.00 \pm 0.14^{\mathrm{a}, \mathrm{B}}$ \\
\hline & 14 & $5.85 \pm 0.35^{\mathrm{a}, \mathrm{A}}$ & $6.65 \pm 0.07 \mathrm{~b}, \mathrm{~A}$ & $6.75 \pm 0.07 \mathrm{~b}, \mathrm{~B}$ \\
\hline & 28 & $6.60 \pm 0.07^{\mathrm{a}, \mathrm{AB}}$ & $6.15 \pm 0.07 \mathrm{a}, \mathrm{A}$ & $6.25 \pm 0.07^{\mathrm{a}, \mathrm{A}}$ \\
\hline \multirow{3}{*}{$\begin{array}{l}\text { Serum ayrılması } \\
\qquad(\mathrm{g} / 10 \mathrm{~g})\end{array}$} & 1 & $3.71 \pm 0.40^{\mathrm{a}, \mathrm{A}}$ & $3.40 \pm 0.08^{\mathrm{a}, \mathrm{A}}$ & $4.17 \pm 0.12^{\mathrm{a}, \mathrm{A}}$ \\
\hline & 14 & $3.43 \pm 0.12^{\mathrm{a}, \mathrm{A}}$ & $3.99 \pm 0.02^{\mathrm{b}, \mathrm{B}}$ & $4.25 \pm 0.21^{\mathrm{b}, \mathrm{A}}$ \\
\hline & 28 & $3.52 \pm 0.06^{\mathrm{a}, \mathrm{A}}$ & $3.70 \pm 0.23^{\mathrm{a}, \mathrm{AB}}$ & $4.01 \pm 0.14^{\mathrm{a}, \mathrm{A}}$ \\
\hline
\end{tabular}

K: Kontrol, ÜÇT1: \%0.5 siyah üzüm çekirdeği tozu ilaveli, ÜÇT2: \%1 siyah üzüm çekirdeği tozu ilaveli yoğurt

A-C Aynı sütundaki farklı büyük harfler ortalama değerler arasındaki istatistiksel farklığı gösterir $(P<0.05)$.

a-c Aynı satırdaki farklı küçük harfler istatistiksel olarak ortalama değerler arasındaki farklılığı gösterir $(P<0.05)$.

Üzüm çekirdeği tartarik, malik, okzalik ve fumarik gibi asitleri içermektedir (Nakilcioğlu-Taş ve Ötleş, 2016). Ayrica depolama süresince laktik asit bakterilerinin laktik asit fermantasyonu sonucu $\mathrm{pH}$ değerleri düşmekte ve asitlik değerleri yükselmektedir (Dave ve Shah, 1997; Ranadheera ve ark., 2012). Yoğurt örneklerinin pH ve asitlik değerlerindeki değişimlerin üzüm çekirdeğinin asit içeriğinden ve laktik asit fermantasyonundan kaynaklandığı düşünülmektedir.

Yoğurt örneklerinde süzme yöntemi ile belirlenen serum ayrılması değerlerinde \%1 ÜÇT içeren örnekte depolama süresince önemli bir değişiklik meydana gelmemiştir. Kontrol ve ÜÇT2 kodlu örneklerin serum ayrılması değerlerinin depolamanın 28. gününde depolamanın 1. gününe göre daha düşük olduğu bulunmuştur. Yalnız depolamanın 14 . gününde $\% 0.5$ ve $\% 1$ ÜÇT ilave edilen örneklerin serum ayrılması değerlerinin kontrol grubuna göre daha yüksek olduğu, depolamanın diğer günlerinde örnekler arasında önemli bir farklılık olmadığı $(\mathrm{P}>0.05)$ tespit edilmiştir. Akın ve Akın (2016) \%0,25, \%0,50 ve \%1 elma lifi ilave ettikleri yoğurtların serum ayrılması değerlerinin depolamanın sonunda (20. Gün) depolamanın ilk gününe göre daha düșük olduğunu belirlemişlerdir. Bakirci ve ark. (2017) farklı oranlarda kabak lifi ilave edilen yoğurtların serum ayrılması değerlerini depolamanın 14. gününde en yüksek kontrol örneğinde $7.12 \mathrm{~mL} / 25 \mathrm{~g}$, en düşük \%1.5 kabak lifi içerek yoğurt örneğinde $2.27 \mathrm{~mL} / 25$ g olarak bulmuşlardır. Bu çalışmadaki değerler Akın ve Akın (2016) ve Bakirci ve ark. (2017) tarafında yapılan çalışmalarda elde edilen bulgular ile benzerlik göstermektedir.

Santrifüj yöntemiyle elde edilen serum ayrılması değerleri Çizelge 1 de gösterilmiştir. Serum ayrılması değerlerinin $3.40 \mathrm{~g} / 10 \mathrm{~g}$ ile $4.25 \mathrm{~g} / 10 \mathrm{~g}$ arasında değiştiği belirlenmiştir. Kontrol ve ÜÇT2 kodlu yoğurt örneklerin serum ayrılması değerlerinin depolama süresince değişim gösterdiği, fakat bu değişimlerin istatistiksel olarak önemsiz olduğu belirlenmiştir ( $\mathrm{P}>0.05)$ \% \% 0.5 ÜÇT ilave edilen yoğurt örneğinin serum ayrılması değerleri depolamanın 14. gününde yükselmiş daha sonra tekrar düşmüştür $(\mathrm{P}<0.05)$. Depolamanın sadece 14. gününde örnekler arasında istatistiksel olarak önemli bir fark $(\mathrm{P}<0.05)$ olduğu tespit edilmiştir. Depolamanın 14. gününde en düşük serum ayrılması değeri kontrol örneğinde (3.43 g /10 g) bulunmuştur. Demirkol ve Tarakci (2018) ve Marchiani ve ark. (2016) yoğurt örneklerinde serum ayrılmasını değerlerini santrifüj yöntemiyle belirlemiş ve örneklerin serum ayrılması değerlerini \%31.99 -\%38.22 ve \%32.34-\%50.86 arasında belirlemişlerdir. Demirkol ve Tarakci (2018)'nın bulduğu değerler bizim değerlerimizden düşük iken, Marchiani ve ark., (2016)'in bulduğu değerler bizim bulduğumuz değerlerden daha yüksekti. Siyah üzüm çekirdeği tozu yüksek lif içeriğine sahiptir (\%71) (Kurt, 2015). Lif ilavesinin yoğurtlarda serum ayrılması üzerinde etkili olduğu bildirilmiştir (Ozcan ve Kurtuldu, 2014).

\section{Viskozite ve reolojik özellikler}

ÜÇT ilavesi yoğurt örneklerinin $50(\mathrm{P}<0.01)$ ve 100 rpm'deki $(\mathrm{P}<0.05)$ viskozite değerleri üzerinde önemli bir etkiye sahipken, kıvam katsayısı $(K)$ ve akış davranış indeksi (n) değerleri üzerindeki 
etkisinin istatistiksel olarak önemsiz $(\mathrm{P}>0.05)$ olduğu bulunmuştur. Yoğurt örneklerinin 50 ve 100 rpm'deki viskozite değerleri en yüksek ÜÇT2 (2754.49 ve $1520.00 \mathrm{cP}$ ) kodlu örnekte, en düşük ise ÜÇT1 (1959.58 ve 1232.03 cP) kodlu örnekte bulunmuştur (Çizelge 2). Tarakçi ve Demirkol (2016) yaptıkları çalışmada $\% 2, \quad \% 3$ ve \%4 oranlarında goji berry meyve tozu ilaveli yoğurtların viskozite değerlerinde istatistiksel olarak önemli değişikliklerin meydana geldiğini belirlemişlerdir. Bakirci ve ark. (2017) diyet lifi ekledikleri yoğurtların viskozite değerlerinin artan lif oranı ile arttığını belirlemişlerdir. Bizim çalışmamızda bulduğumuz sonuçlar Tarakçi ve Demirkol (2016) ve Bakirci ve ark. (2017) tarafından bulunan sonuçlar ile benzerlikler göstermektedir. Demirkol ve Tarakci (2018) yaptıkları çalışmada üzüm posası tozu ilaveli örneklerin viskozite değerlerinin kontrol örneğinden daha düşük olduğunu bulmuşlardır. Bu sonuçlar bizim elde ettimiz sonuçlar ile uyumludur. Bu çalışamdaki viskozite ve kıvam katsayısındaki farklılıkların, yoğurtlara ilave edilen katkılar nedeniyle yoğurdun jel yapısının zayıflayalamasından (Demirkol ve Tarakci 2018) kaynaklanabileceği düşünülmektedir.

Çizelge 2. Siyah üzüm çekirdeği tozu eklenmiş yoğurt örneklerinin viskozite ve bazı reolojik özellikleri

\begin{tabular}{cccc}
\hline & \multicolumn{3}{c}{ Yoğurt Örnekleri } \\
\cline { 2 - 4 } & $\mathrm{K}$ & ÜÇT1 & ÜÇT2 \\
\hline Viskozite $(50 \mathrm{rpm} ; \mathrm{cP})$ & $2089.57 \pm 10.40^{\mathrm{b}}$ & $1239.58 \pm 14.73^{\mathrm{a}}$ & $2754.49 \pm 27.02^{\mathrm{c}}$ \\
Viskozite $(100 \mathrm{rpm} ; \mathrm{cP})$ & $1243.56 \pm 78.88^{\mathrm{b}}$ & $66.65 \pm 10.28^{\mathrm{a}}$ & $1520.00 \pm 42.43^{\mathrm{c}}$ \\
Klvam katsayısı $(K)$ & $95.76 \pm 8.26^{\mathrm{ab}}$ & $0.14 \pm 0.07^{\mathrm{a}}$ & $112.04 \pm 19.93^{\mathrm{b}}$ \\
Akıș davranıș indeksi $(n)$ & $0.06 \pm 0.02^{\mathrm{a}}$ & $0.12 \pm 0.10^{\mathrm{a}}$ & \\
\hline
\end{tabular}

K: Kontrol, ÜÇT1: \%0.5 siyah üzüm çekirdeği tozu ilaveli, ÜÇT2: \%1 siyah üzüm çekirdeği tozu ilaveli yoğurt

a-c Aynı satırdaki farklı küçük harfler istatistiksel olarak ortalama değerler arasındaki farklılı̆ı̆ gösterir $(P<0.05)$.

ÜÇT2 kodlu yoğurt örneği en yüksek $K$ değerine sahip iken (112.04 Pa.sn), ÜÇT1 kodlu örneğin ise en düşük değere sahip olduğu (66.65 Pa.sn) belirlenmiştir (Çizelge 2). Azari-Anpar ve ark. (2017) Aloe vera yapraklarından elde ettikleri jelleri yoğurtlarda kullanmışlar, üretilen yoğurtların reolojik özelliklerini Power Law modeli ile hesaplamışlardır. Bu çalışmada $K$ değerlerini 29.70 ile 70.64 Pa.sn arasında bulmuşlardır. Yoğurt örneklerinin $n$ değerleri arasında önemli bir farklılık tespit edilmemiștir $\quad(\mathrm{P}>0.05)$. Tüm yoğurt örneklerinin akış davranış indeksi değerlerinin Power Law modeline göre 0 ile 1 arasinda bulunmuştur. Buna göre tüm örneklerin psödoplastik akış sergilemiştir. Ürkek ve ark. (2019), Azari-Anpar ve ark. (2017) ve Domagala ve ark. (2005) yaptıkları çalışmalarda yoğurtların akış davranış indekslerini 0 ile 1 arasında olduğunu ve psödoplastik davranış sergilediğini belirlemişlerdir. Yoğurt reolojik olarak stabil olmayan bir sıvidır. Yoğurt tiksotropik bir sıvı gibi davranmasına rağmen yoğurt yapısı bozulduğu zaman tekrar tamamen eski kıvamını kazanamaz. Bu nedenle yoğurt Newtonian olmayan psedöplastik bir sıvıdır (Domagala ve ark., 2005).

\section{Renk parametreleri}

Yoğurt örneklerinin $L^{*}, a^{*}, b^{*}, H^{\circ}, C^{*}(\mathrm{P}<0.01)$ ve BI $(\mathrm{P}<0.05)$ değerleri üzerine ÜÇT ilavesinin etkisinin istatistiksel olarak önemli olduğu tespit edilmiştir. Örneklerin $L^{*}$ değerlerinin artan ÜÇT miktarına bağlı olarak düştügü̈, en yüksek değerin kontrol örneğinde (88.04) en düşük ÜÇT2 kodlu örnekte (77.00) tespit edilmiştir (Çizelge 3). Yoğurtların $a^{*}$ değerleri artan ÜÇT oranı ile yükseldiği, ÜÇT ilaveli örneklerin $a^{*}$ değerlerinin kontrol örneğinden daha yüksek olduğu bulunmuştur. $b^{*}$ değerleri kontrol örneğinde ÜÇT ilaveli örneklere göre daha yüksek olduğu belirlenmiştir. \%0.5 ve \%1 ÜÇT ilave edilen yoğurt örneklerinin $b^{*}$ değerlerinin istatistiksel olarak benzer olduğu $(\mathrm{P}>0.05)$ tespit edilmiştir.

$H^{\circ}$ değerlerinin 91.34 ile 260.09 arasında değiștiği, en yüksek $H^{\circ}$ değeri ÜÇT2 kodlu örnekte, en düşük ise ÜÇT1 kodlu örnekte bulunmuştur. Yoğurt örneklerinin $C^{*}$ değerlerinin ÜÇT1 ve ÜÇT2 kodlu örneklerde kontrol örneğine göre daha düşük olduğu tespit edilmiștir. $\Delta \mathrm{E}^{*}$ değerlerine göre örneklerin renk farklılığının algılanabilir $\left(3 \leq \Delta E^{*}<5\right)$ olduğu tespit edilmiştir. Örneklerin BI değerlerinin ÜÇT ilavesiyle düştüğü, en yüksek BI değeri kontrol örneğinde (80.88) bulunmuştur. ÜÇT1 kodlu örneğin BI değerinin ÜÇT2 örneğinden daha düşük olduğu, buna karşın değerlerin istatistiksel olarak benzer olduğu belirlenmiştir (Çizelge 3). Üzüm çekirdeği gıda sanayinde de renklendirici olarak kullanılan, suda çözünme özelliğine sahip antosiyaninler bakımından zengindir (Rockenbach ve ark., 2011; de 
Souza ve ark., 2015). Üzüm çekirdeği ilaveli yoğurtlardaki renk farklılıkları yoğun antosiyanin varlığı ile ilişkilendirilmektedir.

Çizelge 3. Siyah üzüm çekirdeği tozu eklenmiş yoğurt örneklerinin renk parametreleri

\begin{tabular}{cccc}
\hline & \multicolumn{3}{c}{ Yoğurt Örnekleri } \\
\cline { 2 - 4 } & $\mathrm{K}$ & ÜÇT1 & ÜÇT2 \\
\hline$L^{*}$ & $88.04 \pm 0.38^{\mathrm{c}}$ & $80.81 \pm 0.11^{\mathrm{b}}$ & $77.00 \pm 1.84^{\mathrm{a}}$ \\
$a^{*}$ & $-4.50 \pm 0.52^{\mathrm{a}}$ & $-0.26 \pm 0.03^{\mathrm{b}}$ & $1.83 \pm 0.53^{\mathrm{c}}$ \\
$b^{*}$ & $14.23 \pm 0.62^{\mathrm{b}}$ & $11.63 \pm 0.20^{\mathrm{a}}$ & $10.51 \pm 0.45^{\mathrm{a}}$ \\
$H^{\circ}$ & $107.50 \pm 1.17^{\mathrm{b}}$ & $91.34 \pm 0.23^{\mathrm{a}}$ & $260.09 \pm 3.27^{\mathrm{c}}$ \\
$C^{*}$ & $14.93 \pm 0.74^{\mathrm{b}}$ & $11.76 \pm 0.02^{\mathrm{a}}$ & $10.68 \pm .35^{\mathrm{a}}$ \\
$\Delta \mathrm{E}^{*}$ & - & $4.73 \pm 0.13$ & $5.98 \pm 0.91$ \\
BI & $80.88 \pm 0.83^{\mathrm{b}}$ & $77.55 \pm 0.18^{\mathrm{a}}$ & $74.63 \pm 1.52^{\mathrm{a}}$ \\
\hline
\end{tabular}

K: Kontrol, ÜÇT1: \%0.5 siyah üzüm çekirdeği tozu ilaveli, ÜÇT2: \%1 siyah üzüm çekirdeği tozu ilaveli yoğurt

a-c Aynı satırdaki farklı küçük harfler istatistiksel olarak ortalama değerler arasındaki farklılığı gösterir $(P<0.05)$.

\section{Mikrobiyolojik özellikler}

Yoğurt örneklerinin L. bulgaricus ve S. thermophilus saylları üzerinde ÜÇT ilavesinin ve depolama süresinin etkisinin istatistiksel olarak önemsiz ( $\mathrm{P}>0.05)$ olduğu belirlenmiştir. Örneklerin $L$. bulgaricus saylarının $5.65 \mathrm{log}$ kob/g ile $6.39 \mathrm{log}$ kob/g arasında olduğu bulunmuştur (Çizelge 4). $S$. thermophilus sayıları ise $8.38 \mathrm{log} \mathrm{kob} / \mathrm{g}$ ile $8.67 \mathrm{log}$ kob/g arasında değiștiği belirlenmiştir (Çizelge 4). Tüm örneklerin $L$. bulgaricus ve $S$. thermophilus sayıları depolama süresince artış ve azalışlar göstermiş, fakat bu farkların istatistiksel olarak önemsiz olduğu $(\mathrm{P}>0.05)$ belirlenmiştir. Depolama süresince $L$. bulgaricus ve $S$. thermophilus sayıları bakımından yoğurt örnekleri arasında önemli bir farklılık ( $>0.05)$ meydana gelmemiștir. Demirkol ve Tarakci (2018) yaptıkları çalışmada yoğurtlara farklı şekillerde kurutulmuş üzüm posası tozundan farklı oranlarda ilave etmişler ve 21 gün depolamışlardır. Depolama süresince $L$. bulgaricus ve $S$. thermophilus sayılarında önemli bir farklılık meydana gelmediğini bildirmişlerdir. Bu sonuç bizim çalışmamızda elde ettiğimiz sonuç ile benzerlik göstermektedir.

Çizelge 4. Siyah üzüm çekirdeği tozu eklenmiş yoğurt örneklerinin mikrobiyolojik özellikleri (log kob/g)

\begin{tabular}{|c|c|c|c|c|}
\hline & \multirow{2}{*}{$\begin{array}{c}\text { Depolama } \\
\text { Süresi (gün) }\end{array}$} & \multicolumn{3}{|c|}{ Yoğurt Örnekleri } \\
\hline & & $\mathrm{K}$ & ÜÇT1 & ÜÇT2 \\
\hline \multirow{4}{*}{ L. bulgaricus } & 1 & $5.73 \pm 0.37 \mathrm{a}, \mathrm{A}$ & $5.72 \pm 0.83^{\mathrm{a}, \mathrm{A}}$ & $5.73 \pm 0.33^{\mathrm{a}, \mathrm{A}}$ \\
\hline & 14 & $6.39 \pm 0.13^{\mathrm{a}, \mathrm{A}}$ & $6.15 \pm 0.21^{\mathrm{a}, \mathrm{A}}$ & $6.15 \pm 0.21^{\mathrm{a}, \mathrm{A}}$ \\
\hline & 28 & $5.65 \pm 0.71^{\mathrm{a}, \mathrm{A}}$ & $6.07 \pm 0.40^{\mathrm{a}, \mathrm{A}}$ & $5.99 \pm 0.05^{\mathrm{a}, \mathrm{A}}$ \\
\hline & 1 & $8.38 \pm 0.15^{\mathrm{a}, \mathrm{A}}$ & $8.59 \pm 0.02^{\mathrm{a}, \mathrm{A}}$ & $8.46 \pm 0.04^{\mathrm{a}, \mathrm{A}}$ \\
\hline \multirow{3}{*}{ S. thermophilus } & 14 & $8.55 \pm 0.22^{\mathrm{a}, \mathrm{A}}$ & $8.47 \pm 0.08^{\mathrm{a}, \mathrm{A}}$ & $8.47 \pm 0.07^{\mathrm{a}, \mathrm{A}}$ \\
\hline & 28 & $8.67 \pm 0.11^{\mathrm{a}, \mathrm{A}}$ & $8.54 \pm 0.06^{\mathrm{a}, \mathrm{A}}$ & $8.53 \pm 0.05^{\mathrm{a}, \mathrm{A}}$ \\
\hline & 1 & $<2$ & $<2$ & $<2$ \\
\hline \multirow[t]{2}{*}{ Maya-küf } & 14 & $<2$ & $<2$ & $<2$ \\
\hline & 28 & $<2$ & $<2$ & $<2$ \\
\hline
\end{tabular}

K: Kontrol, ÜÇT1: \%0.5 siyah üzüm çekirdeği tozu ilaveli, ÜÇT2: \%1 siyah üzüm çekirdeği tozu ilaveli yoğurt

A-C Aynı sütundaki farklı büyük harfler ortalama değerler arasındaki istatistiksel farklığı gösterir $(P<0.05)$.

a-c Aynı satırdaki farklı küçük harfler istatistiksel olarak ortalama değerler arasındaki farklılığı gösterir $(P<0.05)$.

Fenolik bileşikler ve bakteriler tarafından üretilen metabolitler farklı bakterilerin gelişmesini engelleyebilmektedir. Özellikle fenolik bileşikler antibakteriyel etkiler gösterebilmektedir (SunWaterhouse ve ark., 2013; Demirkol ve Tarakci, 2018). Yapılan bir çalışmada üzüm ekstraktı ilavesinin yoğurt örneklerinin L. bulgaricus ve $S$. thermophilus sayılarını etkilediği, düşüşlere neden olduğu belirlenmiștir (da Silva ve ark., 2017). Üzüm çekirdeği fenolik bileşikler bakımından zengin olup (Rockenbach ve ark., 2011; Al-Taie, 2014), bizim çalışmamızdaki bakteri sayıları feneolik bileşikler tarafından baskılanmış olabilir.

Yoğurt örneklerinin maya küf sayıları depolama süresince tüm örneklerde <2 log kob/g olarak belirlenmiştir (Çizelge 4). Ürkek ve ark., (2019) ayva tozu ilave ederek ürettikleri yoğurtların maya küf sayılarını depolama süresince $<2$ log kob/g olarak bulmuşlardır. $\mathrm{Bu}$ sonuçlar bizim çalışmamız ile benzerlik göstermektedir. Yoğurt üretiminin önemli bir işlem basamağı pastörizasyon olup, maya küf sayısı kontaminasyonun bir göstergesidir. Özellikle de meyveli yoğurtlar için maya ve küfler önemli bir problem kaynağı olabilir (Nogueira ve ark., 1998). Fenolik bileşikleri bazı bakterilerin ve maya-küflerin gelişimini engelleyebilmektedirler (Chouchouli ve ark., 2013) ÜÇT ilaveli yoğurtlarda maya küf sayısı fenolik bileşiklerden etkilenmiş olabilir. Kontrol örneğinde maya küf tespit edilememesi ise pastörizasyondan sonra herhangi bir 
kontaminasyonun olmadığının göstergesi olarak kabul edilebilir.

\section{Duyusal özellikler}

Yoğurt örneklerinin renk ve görünüş, lezzet, tat ve koku, ağızda bıraktığı his ve genel kabul edilebilirlik özellikleri üzerine üzüm çekirdeği tozu ilavesinin etkisinin istatistiksel olarak önemli $(\mathrm{P}<0.05)$ olduğu, yapı ve tekstür özelliklerinin etkilenmediği belirlenmiştir $\quad(\mathrm{P}>0.05)$ \%1 ÜÇT ilave edilen örneklerin tüm özellikler bakımından aldığı puanlar kontrol örneğine göre daha düşüktü (Şekil 2). Kontrol örneği renk ve görünüş, yapı ve tekstür, lezzet, tat ve koku, ağızda bıraktığı his ve genel kabul edilebilirlik değerlendirmelerinde panelistlerden en yüksek puanları almıştır. \%0.5 ÜÇT ilaveli örneklerin tüm değerlendirme puanlarının \%1 ÜÇT ilaveli örneklere göre daha yüksek olduğu belirlenmiștir. Demirkol ve Tarakci (2018) yaptıkları çalışamda yoğurda ilave edilen üzüm posası tozu ileve etmişler ve üzüm posası tozu ilave edilen örneklerin duyusal puanlarının kontrol örneğine daha düşük olduğunu ve daha az beğenildiğini bulmuşlardır.

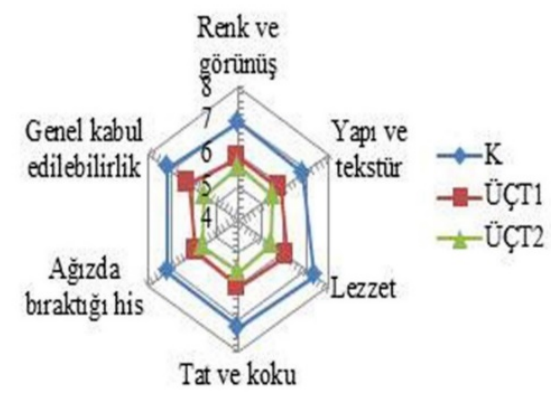

Şekil 2. Siyah üzüm çekirdeği tozu eklenmiş yoğurt örneklerinin duyusal özellikleri (K: Kontrol, ÜÇT1: \%0.5 siyah üzüm çekirdeği tozu ilaveli, ÜÇT2: \%1 siyah üzüm çekirdeği tozu ilaveli yoğurt)

Gıdalarda fenolik bileşikler acılık ve buruk tadın oluşmasında etkin rol oynamaktadırlar (Pedan ve ark., 2019). Dolayısıyla, ÜÇT ilaveli yoğurt örneklerinin kontrol örneğine göre daha düşük puanlar almasında fenolik bileşiklerin etkili olduğu ve yoğurtların duyusal özelliklerinin depolamanın sonunda değerlendirilmesi sonucu fenolik bileşiklerin daha fazla çözünmüş olmasından kaynaklanabileceği düşünülmektedir.

\section{Sonuç}

$\mathrm{Bu}$ çalışmada farklı oranlarda ÜÇT ilave edilen yoğurtların bazı fizikokimyasal $(\mathrm{pH}$, asitlik ve serum ayrılması) ve mikrobiyolojik özellikleri araştırılmıştır. Yoğurt örneklerinin reolojik, renk ve duyusal özellikleri ise depolamanın sonunda belirlenmiştir. \%1 ÜÇT ilave edilen yoğurt örneklerinin viskozite ve reolojik değerleri yükselirken, serum ayrılması değerleri düşmüştür. ÜÇT ilaveli örneklerin renk parametrelerinde kontrol örneklerine göre önemli değişimler olduğu tespit edilmiştir. Duyusal özellikler bakımından ÜÇT ilaveli örnekler kontrol örneğine göre daha düşük puanlar almıştır. Sonuç olarak ÜÇT yoğurtlarda renklendirici olarak kullanılabilir. Reolojik özellikler bakımından ÜÇT ilavesinin olumlu etkisi olmasına karşın, duyusal özellikler bakımından beğenilmediğinden ÜÇT ilavesinin \%0.5'in altında tutulması tavsiye edilebilir.

\section{Kaynaklar}

Akın, M.S., \& Akın, M.B. (2016). Elma lifi ile zenginleștirmenin set tipi yoğurtların bazı özelliklerine etkisi. Harran Tarım ve Gıda Bilimleri Dergisi, 20(2), 94-104.

Akin, M.B., Akin, M.S., \& Kirmaci, Z. (2007). Effects of inulin and sugar levels on the viability of yogurt and probiotic bacteria and the physical and sensory characteristics in probiotic ice-cream. Food Chemistry, 104, 93-99.

Al-Taie, K.L.S. (2014). Antimicrobial effect of black grape seed extract. Iraqi Journal of Science, 55, 382-385.

Anonim, (2018). Tarım Ürünleri Piyasaları: Üzüm. Tarımsal Ekon. ve Polit. Geliştirme Enstitüsü 3-6.

Atamer, M., \& Sezgin, E. (1986). Yoğurtlarda, kurumadde arttırımının pıhtının fiziksel özellikleri üzerine etkisi. Gıda Dergisi, 11, 327-331.

Azari-Anpar, M.H., Payeinmahali, Daraei Garmakhany, A., \& Sadeghi Mahounak, A. (2017). Physicochemical, microbial, antioxidant, and sensory properties of probiotic stirred yoghurt enriched with Aloe vera foliar gel. Journal of Food Processing and Preservation, 41, 1-9.

Bakirci, S. E., Dagdemir, Boran, O.S., \& Hayaloglu, A.A. (20179. The effect of pumpkin fibre on quality and storage stability of reduced-fat set-type yogurt. International Journal of Food Science Technology, 52, 180-187.

Bashimov, G. (2017). Türkiye'de üzüm üretimi ve ihracat performansı. Uludağ Üniversitesi Ziraat Fakültesi Dergisi, 31, 57-68.

Brückner-Gühmann, M., Benthin, A., \& Drusch, S. (2019). Enrichment of yoghurt with oat protein fractions: Structure formation, textural properties and 
sensory evaluation. Food Hydrocolloids, 86, 146153.

Cecchini, M., Contini, M., Massantini, R., Monarca, D., \& Moscetti, R. (2011). Effects of controlled atmospheres and low temperature on storability of chestnuts manually and mechanically harvested. Postharvest Biology and Technology, 61, 131-136.

Chouchouli, V.N., Kalogeropoulos, S.J., Konteles, E., Karvela, Makris, D.P., \& Karathanos, V.T. (2013). Fortification of yoghurts with grape (Vitis vinifera) seed extracts. LWT- Food Science and Technology, $53,522-529$

Da Silva, D.F., Junior, N.N.T., Gomes, R.G., dos Santos Pozza, M.S., Britten, M., \& Matumoto-Pintro, P.T. (2017). Physical, microbiological and rheological properties of probiotic yogurt supplemented with grape extract. Journal of Food Science and Technology, 54, 1608-1615.

Dave, R.I., \& Shah, N.P. (1997). Effect of cysteine on the viability of yoghurt and probiotic bacteria in yoghurts made with commercial starter cultures. International Dairy Journal, 7(8-9), 537-545.

De Souza, V.B., Thomazini, M., Balieiro, J.C.D.C., \& FávaroTrindade, C.S. (2015). Effect of spray drying on the physicochemical properties and color stability of the powdered pigment obtained from vinification byproducts of the Bordo grape (Vitis labrusca). Food and Bioproducts Processing, 93, 39-50.

Demirkol, M., \& Tarakci, Z. (2018). Effect of grape (Vitis labrusca L.) pomace dried by different methods on physicochemical, microbiological and bioactive properties of yoghurt. LWT- Food Science and Technology, 97, 770-777.

Domagala, J., Sady, M., Grega, T., \& Bonczar, G. (2005). The influence of storage time on rheological properties and texture of yoghurts with the addition of oatmaltodextrin as the fat substitute. International Journal of Food Properties, 8(3), 439-448.

Guénard-Lampron, V. D., St-Gelais, Villeneuve, S., \& Turgeon, S.L. (2019). Individual and sequential effects of stirring, smoothing, and cooling on the rheological properties of nonfat yogurts stirred with a technical scale unit. Journal of Dairy Science, 102, 190-201.

Karaaslan, M.M., Ozden, Vardin, H., \& Turkoglu, H. (2011). Phenolic fortification of yogurt using grape and callus extracts. LWT- Food Science and Technology, 4, 1065-1072.

Kurt, A., \& Atalar, I. (2018). Effects of quince seed on the rheological, structural and sensory characteristics of ice cream. Food Hydrocolloids, 82, 186-195.

Kurt, Ş. (2015). The effects of grape seed flour on the raw and cooked beef patties quality. Veterinarija ir Zootechnika, 69, 34-37.

Marchiani, R.M., Bertolino, S., Belviso, Giordano, M., Ghirardello, D., Torri, L., Piochi, M., \& Zeppa, G. (2016). Yogurt enrichment with grape pomace: effect of grape cultivar on physicochemical, microbiological and sensory properties. Journal of Food Quality, 39, 77-89..

McLellan, M.R., Lind, L.R., \& Kime, R.W. (1995). Hue angle determinations and statistical analysis for multiquadrant Hunter L, a, b data. Journal of Food Quality, 18, 235-240.

Meilgaard, M.C., Carr, B.T., \& Civille, G.V. (1999). Sensory Evaluation Techniques. 3rd ed.

Metin, M. (2009). Süt ve Mamulleri Analiz Yöntemleri. EÜ, Ege Meslek Yüksekokulu Yay. No: 24, İzmir, Turkey.

Nakilcioğlu-Taş, E., \& Ötleş, S. (2016). Basınçlı su ekstraksiyonuyla elde edilen üzüm çekirdeği ekstraktının polifenol ve organik asit içeriğinin belirlenmesi. Bahçe, 45(2), 67-75.

Nogueira, C.H., Albano, Gibbs, P., \& Teixeira, P. (1998). Microbiological quality of Portuguese yogurts. Journal of Industrial Microbiology Biotechnology, 21, 19-21.

Ozcan, T., \& Kurtuldu, O. (2014). Influence of dietary fiber addition on the properties of probiotic yogurt. International Journal of Chemical Engineering and Applications, 5, 397-401.

Pedan, V., Popp, M., Rohn, S., Nyfeler, M., \& Bongartz, A. (2019). Characterization of phenolic compounds and their contribution to sensory properties of olive oil. Molecules, 24(11), 2041.

Ranadheera, C.S., Evans, C.A., Adams, M.C., \& Baines, S.K. (2012). Probiotic viability and physico-chemical and sensory properties of plain and stirred fruit yogurts made from goat's milk. Food Chemistry, 135(3), 1411-1418.

Rockenbach, I.I., Rodrigues, E., Gonzaga, L.V., Caliari, V., Genovese, M.I., Gonalves, A.E.D.S.S., \& Fett, R. (2011). Phenolic compounds content and antioxidant activity in pomace from selected red grapes (Vitis vinifera L. and Vitis labrusca L.) widely produced in Brazil. Food Chemistry, 127, 174-179.

Rosales Soto, M.U., Brown, K., \& Ross, C.F. (2012). Antioxidant activity and consumer acceptance of grape seed flour-containing food products. International Journal of Food Science Technology, 47, 592-602.

Sendra, E., Fayos, P., Lario, Y., Fernández-López, J., SayasBarberá, E., \& Pérez-Alvarez, J.A. (2008). Incorporation of citrus fibers in fermented milk 
containing probiotic bacteria. Food Microbiology, $25,13-21$.

Sun-Waterhouse, D., Zhou, J. \& Wadhwa, S.S. (2013). Drinking yoghurts with berry polyphenols added before and after fermentation. Food Control, 32, $450-460$

Şengül, M., Erkaya, T., Şengül, M., \& Yıldız, H. (2012). The effect of adding sour cherry pulp into yoghurt on the physicochemical properties, phenolic content and antioxidant activity during storage. International Journal of Dairy Technology, 65, 429436.
Tarakçi, Z., \& Demirkol, M. (2016). Yoğurdun fizikokimyasal özelliklerine kurutulmuş goji berry meyvesinin (Lycium barbarum) etkisi. Ordu Üniversitesi Bilim ve Teknoloji Dergisi, 6(2), 136145.

Ürkek, B., Şengül, M., Aktaş, H., \& Gürbüz, Z. (2019). Effects on some physicochemical, rheological and microbiological characteristics of yoghurt enriched with quince powder. 3rd International Conference on Agriculture, Food, Veterinary and Pharmacy Sciences (ICAFOP), (16-18 April 2019, Trabzon), 992-998. 